DOI: 10.35340/2308-104X.2019.85-4-02

\section{ВПЛИВ ГЕОПОЛІТИЧНИХ ЧИННИКІВ НА ЕКОНОМІЧНИЙ РОЗВИТОК УКРАЇНИ}

\author{
THE INFLUENCE OF \\ GEOPOLITICAL FACTORS ON \\ THE ECONOMIC \\ DEVELOPMENT OF UKRAINE
}

\author{
КЕНДЮХОВ О. В., \\ доктор економічних наук, \\ професор, професор кафедри \\ управління персоналом i \\ маркетингу, Запорізький \\ національний університет \\ БОЛГОВ В. С., \\ кандидат економічних наук, \\ доцент кафедри підприсмництва, \\ корпоративної та просторової \\ економіки, Донецький \\ національний університет \\ ім. Василя Стуса
}

\author{
KENDJUHOV O., \\ Doctor of Economic Sciences, \\ Professor, Department of Personnel \\ Management and Marketing, \\ Zaporizhzhya National \\ University \\ BOLHOV V., \\ Candidate of Economic Sciences, \\ Associate Professor, Department \\ of Entrepreneurship, Corporate \\ and Spatial Economics, Vasyl \\ Stus Donetsk National \\ University
}

У статті проаналізовано напрямки сучасних геополітичних зрушень, що визначають майбутні сценарії розвитку світового порядку, дотримуючись яких можна розробити стратегію розвитку держави з урахуванням головних національних інтересів та забезпечити стійкий економічний розвиток. Наведено бачення розвитку промислових револючій та надано характерні риси останньої з них. Зроблено спробу визначення пропозицій щодо використання геополітичних чинників задля забезпечення розвитку України.

Ключові слова: геополітика, індустріальна револючія, розвиток, екологія, довкілля, ресурси, промисловість, глобальна економіка.

B cтатье проанализированы направления современных геополитических сдвигов, определяющих будущчие сиенарии развития мирового порядка, следуя которым можно разработать стратегию развития государства с учетом главных начиональных интересов $и$ обеспечить устойчивое экономическое развитие. Предложено видение развития промышленных револючий, и предоставлено характерные черты последней из них. Сделана попытка определения предложений относительно использования геополитических факторов для обеспечения развития Украины.

Ключевые слова: геополитика, индустриальная револючия, развитие, экология, окружающая среда, ресурсы, промышленность, глобальная экономика.

The article analyzes the directions of modern geopolitical shifts that determine future scenarios for the development of the world order, following which it is possible to develop a state development strategy taking into account 
the main national interests and ensure sustainable economic development. The vision of the development of industrial revolutions is given, and the characteristic features of the last of them are provided. An attempt is made to identify proposals for the use of geopolitical factors to ensure the development of Ukraine.

Keywords: geopolitics, industrial revolution, development, ecology, environment, resources, industry, global economy.

Постановка проблеми. Початок XXI сторіччя характеризується динамічними змінами в глобальному геополітичному просторі. Зміна різних зовнішніх факторів призвела до переосмислення багатьма країнами свого місця та ролі в сценарії глобальних зрушень та орієнтирів власного розвитку. Наша держава, відчула на собі всі наслідки глобальних коливань. Відсутність власного фарватеру - бачення розвитку та особистої ролі в цих процесах призводить до того, що Україна опиняється в завідомо програшних позиціях.

Аналіз останніх досліджень і публікацій. Проблема економічного розвитку та їі зв'язок з геополітичними процесами останнім часом все частіше залучають до себе увагу вітчизняних фахівців, науковців та суспільних діячів. Так, до науковців, що активно займаються вивченням цієї теми можна віднести: Кіндзерського Ю. В., Сіденко В. Р., Лютого І. О., Ставицький А., Ящишину І. В. та інших.

Особливістю цієї статті є формування комплексного погляду на розвиток держави з урахуванням детермінант останньої промислової революції.

Метою статmі є дослідження напрямків сучасних глобальних геополітичних зрушень та спроба окреслити напрямки розробки власної геополітичної стратегії для України, що забезпечить стійкий економічний розвиток.

Виклад основного матеріалу дослідження. Головними геополітичними викликами, що стоять перед Україною та формують порядок денний ії зовнішньої та внутрішньої політики є:

руйнація світового укладу, що склався після II Світової війни;

зміна клімату, навколишнє середовище та природні ресурси;

формування нової індустріальної (промислової) революції.

У контексті вказаних пунктів розглянемо сутність формування вітчизняної геополітичної стратегії, що забезпечить стійкий економічний i політичний розвиток.

У розрізі першого пункту Україна опинилась у вирі подій, а саме бореться 3 наслідками гібридної російської агресії та нездатністю міжнародного права протидіяти порушенням домовленостей. Справедливості ради необхідно зазначити, що слідком за Росією не стали дотримуватись багатосторонніх угод i інші країни підписанти та гаранти миру та недоторканності. Таке становище стало можливим:

по-перше, через відсутність суб'єктності в геополітичній поведінці вітчизняної дипломатії;

по-друге, тенденції до перегляду міжнародних угод набуває все більших масштабів по всьому світу. В економічному сенсі, в багатьох країнах світу набуває популярності політика протекціонізму, що руйнує теорію глобальної вільної 
торгівлі. Яскравим прикладом є Brexit Великої Британії з СС та торгівельна війна між США і Китаєм.

Важливим фактором, що може змінити геополітичний розподіл сил та вплинути на розвиток як окремих країн так і світового господарства в цілому $є$ кліматичні зміни, як стверджує Дж. Бабсі: «Саме вони створюють суттєвіший вплив на глобальну економіку та зовнішню політику за інші фактори разом взяті» [5].

Так, лише в 2017 році від стихійних лих втрати США становили понад 300 млрд дол. [5].

Підвищення рівня моря, зменшення сільськогосподарських угідь та питної води, придатної до вживання, робить країни з запасами таких ресурсів досить привабливими та потенційно впливовими.

Однак, визначальним фактором завжди лишається економічний базис, що обумовлює формування внутрішньої та зовнішньої політики держави.

У фундаментальних положеннях відносно засад економічного розвитку відбувається пришвидшення розвитку теорій та визначальних поглядів. В глобальному значенні прийнято говорити про чотири індустріальні (промислові) революції. Можна впевнено стверджувати, що світова економіка перебуває в розпалі розвитку 4-ої промислової революції, для якої є притаманним наявність в світі протилежно направлених течій. 3 одного боку, в розвинених країнах та країнах з перехідною економікою відбувається деіндустріалізація, а в країнах, що розвиваються навпаки, швидкими темпами впроваджується індустріалізація.

Для розробки орієнтиру розвитку необхідно більш детально розібрати вказані процеси та визначити положення України в них.

Деіндустріалізація, що спостерігається в розвинених та країнах 3 перехідною економікою, базується на концептуально різних процесах. Під «зрілою» деіндустріалізацією, що відбувається в високорозвинених країнах слід розуміти процеси, внаслідок яких промислове виробництво, втрачаючи відсоткову частку у ВВП, не скорочує свого натурального виразу, а трансформується у високотехнологічні галузі, що є наслідком НТП, та в свою чергу формує базу для подальшого розвитку продуктивності праці та розширенню інновацій. Так, з 1990 року по 2016 рік в цих країнах частка промислового виробництва у ВВП скоротилася з 28,3\% до 18,5\% [1, с.7].

Водночас, країни що розвиваються, стрімко нарощують обсяги промислового виробництва як в натуральному значенні, так і відносно частки ВВП країни.

У країнах 3 перехідною економікою, до яких належить Україна, спостерігаються процеси так званої «передчасної» деіндустріалізації, для якої притаманне зменшення промислового виробництва як у абсолютному значенні, так і відносно ВВП. В цих країнах з 1990 року по 2016 рік в середньому частка промисловості в загальному обсязі ВВП скоротилася з 38,3\% до 28,2\% [1, с.7].

Якщо проаналізувати значення натуральних показників, то видно, що в розвинутих країнах обсяги промислового виробництва за період 1990-2016 роки зріс в 1,9 рази, в країнах що розвиваються, за той самий період, в середньому в 3,5 рази, при чому лідерами стали Південна Корея - 5 разів, та Китай - 15 разів, в країнах 3 перехідною економікою промисловість продемонструвала падіння майже на $12 \%[1$, с.7]. 
Дехто з науковців схильні стверджувати про початок розвитку нової п’ятої промислової революції, прихильники такої точки зору в якості доказів демонструють данні, згідно 3 якими в розвинених країнах розпочинається промисловий ренесанс [3, с.11]. Так, влада США за допомогою податкових інструментів втілює програму «re-shoring» - повернення в країну виробництв, що раніше були виведені, при цьому акцент робиться саме на наукомісткій промисловості [2, с.8].

Таким чином, схематично розвиток промислових революцій умовно можна зобразити за допомогою рис.1.

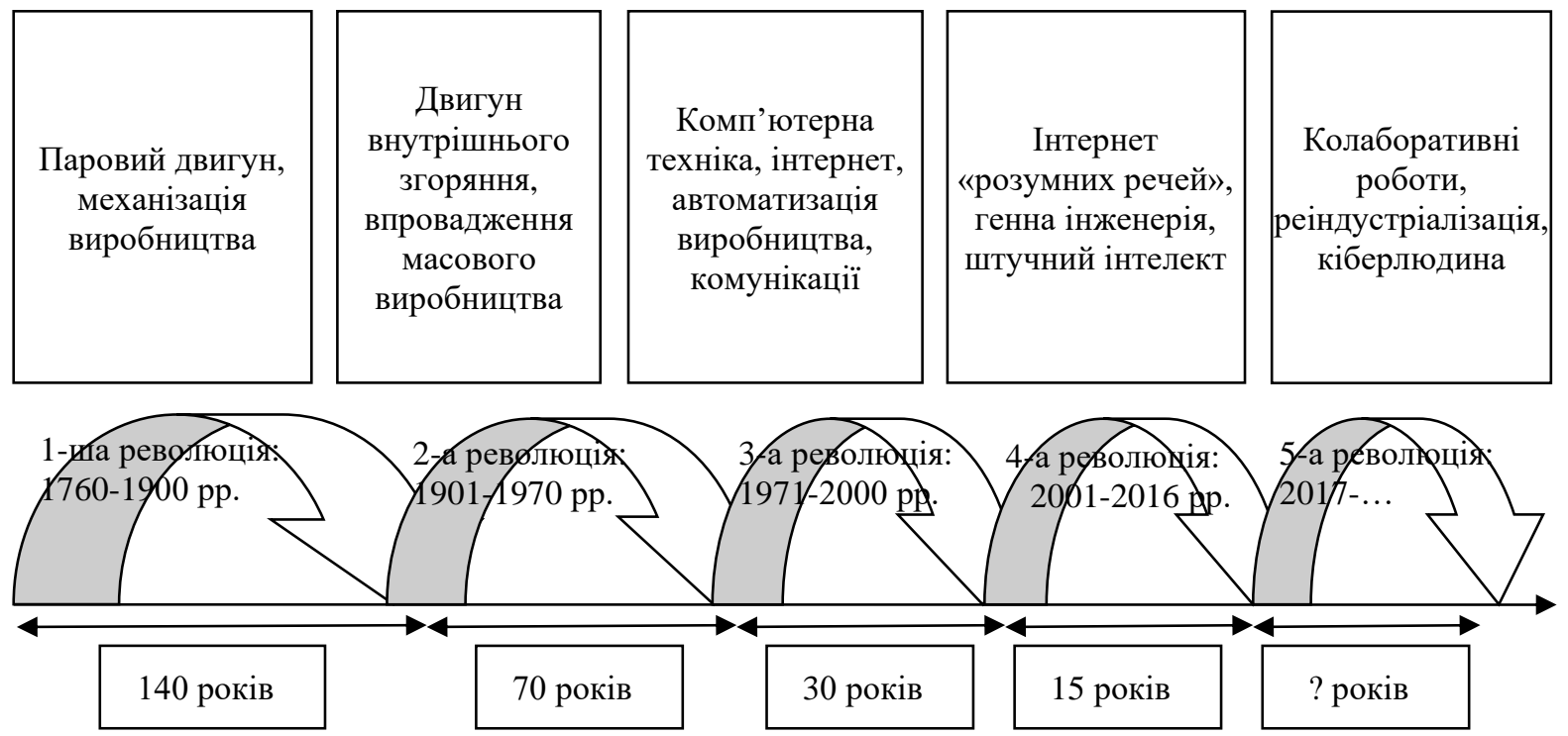

Рис. 1. Розвиток промислових революцій

Країни ЄС намітили підвищити частку промисловості в загальному обсязі ВВП до 20\% в наступному 2020 році, що на 4\% більше, ніж в 2012 році. В межах реалізації цього плану поставлена задача довести фінансування витрат на НДДКР до 3\% ВВП. Вже зараз спостерігається, що європейська промисловість забезпечує 65\% цього фінансування, а їі інноваційна активність в двічі перевищує показники інших галузей $[1$, c.13]. Саме ці процеси обумовлюють підвищення продуктивності праці в цих країнах. Дослідження зміни продуктивності праці наведено в табл. 1.

Таблиця 1

Зміна продуктивності праці за 1 годину, дол США 2000-2016 pp. [6]

\begin{tabular}{|l|c|c|}
\hline \multicolumn{1}{|c|}{ Країна } & $2000 \mathrm{p}$. & $2016 \mathrm{p}$. \\
\hline США & 50,4 & 62,9 \\
\hline СС - 28 & 40,2 & 47,4 \\
\hline Україна & 5,8 & 7,9 \\
\hline
\end{tabular}

П’ята промреволюція базується на поверненні вирішальної ролі люди у виробничий процес. Це відбувається за декількома причинами:

споживач, втомлений безликістю масового виробництва, все частіше шукає індивідуального підходу до товарного виробництва; 
масова роботизація, до якої прагнула 4-а революція, загрожує новою проблемою - масовим структурним безробіттям, а як наслідок - деградацією суспільства.

По всьому світу спостерігається тенденція до скорочення середнього класу, який є локомотивом креативності, прогресу та інновацій. Виведення людини 3 виробничого процесу виводить ii $\mathrm{i} 3$ кола споживачів. Тому в експертному середовищі піднімається питання про впровадження «базового доходу» щомісячних виплат громадянам країни незалежно від наявності у них роботи. Економісти та політики сходяться на тому, що необхідні розробки та впровадження етичного кодексу, використання промислових роботів на кшталт того, що діє в генній інженерії. Все частіше говориться не про заміну людини роботом, а їх синтез, синергію [9].

Таким чином, можна стверджувати, що п'ята промислова революція базується на досягненнях четвертої, але додає їм гуманістичного забарвлення, тобто ії базою є не технологічні, а суспільні інновації.

За теорією «переваги відставання» та з урахуванням значного наукового людського та ресурсного потенціалу Україна має добрі можливості на успішне впровадження засад п'ятої промислової революції з метою забезпечення швидких темпів економічного розвитку. Для цього наша держава має запропонувати новаторські засади суспільних та соціокультурних відносин.

Висновки $i$ перспективи подальших досліджень. 3 метою вирішення проблем, пов'язаних із трьома головними геополітичними викликами необхідна розробка комплексної стратегічної концепції розвитку України з чітким баченням внутрішнього укладу, власного місця і ролі в світових відносинах.

Кожен окремий аспект із визначеної тріади проблем потребує більш детального вивчення та розробки інструментів їх подолання в розрізі загальної філософії концепції розвитку нашої держави, для цього необхідно залучення фахівців з галузей міжнародного права, політології та юриспруденції.

\section{Лimepamypa:}

1. Кіндзерський Ю. В. Соціальні дисфункції технологічного прогресу або латентні виклики нової промислової революції. Перспективи розвитку міжнародних відносин: економічні та політичні аспекти: матеріали доповідей міжнародної науково-практичної конференції. ( м. Ужгород 21.05.2019). Ужгород, 2019. С. 83-86.

2. Сіденко В.Р. Глобальні структурні трансформації та тренди економіки України. Економіка і прогнозування. 2018, № 2. С. 7-29.

3. Лютий І. О., Карпич А. Ю. Цифрові токени у фінансуванні приватного бізнесу: монографія. К.: Видавництво Ліра-К, 2019. 188 с.

4. Коли почнеться п'ята промислова революція? Як вона змінить світ? URL: https://uk.etcetera.media/6881-99.html.

5. Лук'янчук С. Планета нагрівається, міста заливає. Як кліматичні зміни впливають на життя та світову політику. URL: http://texty.org.ua/ pg/article/newsmaker/read/87229/Planeta_nagrivajetsa_mista_zalyvaje_Jak_klimatych ni_zminy.

6. Ставицький А. Вплив сучасних геополітичних викликів на економічну безпеку держави. Вісник Київського національного університету імені Тараса 
Шевченка. 2018, № 4(199). С. 45-55.

7. Ящишина I. В. Інноваційність глобальної конкурентоспроможності України. Економіка в контексті інноваційного розвитку: стан та перспективи. Ужгород: Видавничий дім «Гельветика», 2016. Ч. 2. С.43-45.

8. Industry as a growth in the global economy. Institut der deutschen Wirtschaft Köln / Lichtblau K. and other. Cologne: IW Köln, 2013. 162 p.

9. Metz C. The Al Threat Isn`t Skynet. It`s the End of the Middle Class. Wired. 2017. February 10. URL:httpc://www.wired.com/2017/02/ai-threat-isnt-skynet-endmiddle-class.

\section{References:}

1. Kindzersjkyj Ju. V. Socialjni dysfukciji tekhnologhichnogho proghresu abo latentni vyklyky novoji promyslovoji revoljuciji. Materialy dopovidej mizhnarodnoji naukovo-praktychnoji konferenciji Perspektyvy rozvytku mizhnarodnykh vidnosyn: ekonomichni ta politychni aspekty. m. Uzhghorod 21.05.2019 r., S. 83-86.

2. Sidenko V. R. Ghlobaljni strukturni transformaciji ta trendy ekonomiky Ukrajiny. Ekonomika i proghnozuvannja. 2018, \# 2, S. 7-29.

3. Ljutyj I. O., Karpych A. Ju. Cyfrovi tokeny u finansuvanni pryvatnogho biznesu: monoghrafija. K.: Vydavnyctvo Lira-K, 2019. 188 s.

4. Koly pochnetjsja p'jata promyslova revoljucija? Jak vona zminytj svit? URL: https://uk.etcetera.media/6881-99.html

5. Luk'janchuk S. Planeta naghrivajetjsja, mista zalyvaje. Jak klimatychni zminy vplyvajutj na zhyttja ta svitovu polityku. URL: http://texty.org.ua/pg/article/newsmaker/read/87229/Planeta_nagrivajetsa_mista_zalyv aje_Jak_klimatychni_zminy

6. Stavycjkyj A. Vplyv suchasnykh gheopolitychnykh vyklykiv na ekonomichnu bezpeku derzhavy. Visnyk Kyjivsjkogho nacionaljnogho universytetu imeni Tarasa Shevchenka. 2018, \# 4(199), S. 45-55.

7. Jashhyshyna I. V. Innovacijnistj ghlobaljnoji konkurentospromozhnosti Ukrajiny. Ekonomika $\mathrm{v}$ konteksti innovacijnogho rozvytku: stan ta perspektyvy: materialy Mizhnarodnoji nauk.-prakt. konf. Uzhghorod: Vydavnychyj dim «Gheljvetyka», 2016. Ch. 2. S.43-45.

8. Industry as a growth in the global economy / Lichtblau K. and other. Institut der deutschen Wirtschaft Köln. Cologne: IW Köln, 2013. 162 p.

9. Metz C. The Al Threat Isn`t Skynet. It`s the End of the Middle Class. Wired. 2017. February 10. URL:httpc://www.wired.com/2017/02/ai-threat-isnt-skynet-endmiddle-class.

Recently, global geopolitical relations have tended to undergo dynamic changes, with the result that different states are losing their subjectivity and the basis of economic development. Thus, determining the essence of the factors that determine the direction of these processes will help to develop a comprehensive strategy of state development to ensure sustainable economic development.

The article describes and considers the main geopolitical factors of the development of the state, the main of which is economic. 
The main geopolitical challenges facing Ukraine and shaping the agenda of its foreign and domestic policy are:

the destruction of the world order after the second world war;

climate change, environment and natural resources;

formation of a new industrial (industrial) revolution.

The article analyzes the current trends in providing the basis for economic development in different countries of the world. The place of Ukraine in the tendencies of development of labor productivity and creation of own production base is revealed. It is revealed that in recent years the processes of reindustrialisation in developed countries have been going on and their foundations have been defined. The author's vision of the evolution of the Industrial Revolution is offered. The assumption about the essence of the Fifth Industrial Revolution and the main prerequisites for its implementation are outlined.

The Fifth Industrial Revolution is based on the return of the crucial role of people in the production process. This happens for several reasons:

consumers are tired of the masslessness of mass production, increasingly seeking an individual approach to commodity production;

the mass robotization that the 4 th revolution was striving for threatens a new problem - mass structural unemployment, and as a consequence of the degradation of society.

Suggestions are made to strengthen the geopolitical position of our state through ensuring the leadership positions of Ukraine in the process of introducing the foundations of the fifth industrial revolution.

Thus, in order to solve the problems related to the three major geopolitical challenges facing Ukraine, it is necessary to develop a comprehensive strategic concept of the country's development with a clear vision of the internal structure, social relations, own place and role in the world arena. 